\section{4. 統}

\section{1 テレビジョン放送関係の統計}

テレビ放送は 1989 年 3 月末現在, NHK が総合, 教育合わせて 6912 局，民間放送 (民放) が 103 社 6594 局である NHK と民放の局数は接近してきており， やがては逆転する状況にある(図 1) NHKの放送局 数は 1984 以降ほほ横ばいで, 1987 年からは減少に転 じている（図 2）この間, 衛星放送の受信世帯数が急 激な増加に転じた（図 3) 特に個別受信の増加が著し く,89 年 9 月には共同受信世帯数を上回った

CATV はこの 5 年間に 6969 施設増え, 受信契約者

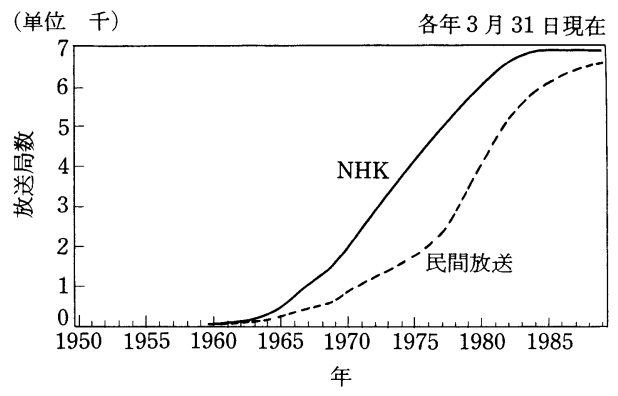

凶 1 NHK およひ民間テレヒ放送局数の推移 ${ }^{12)}$

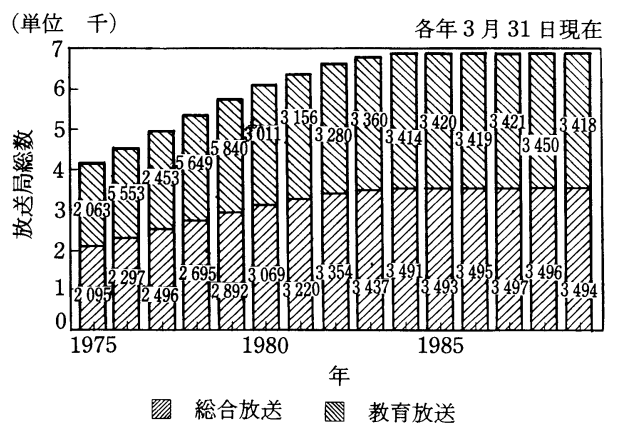

凶 2 NHK 放送局数の推移 ${ }^{11}$

†郵政省 通信総合研究所

14 "Stastitics" by Chiharu Ohuchı (Communications Research Laboratory, Ministry of Posts and Telecommunications, Tokyo)

$912(94)$
計

14.1,14.2 大 内 智 晴 $^{\dagger}($ 正会員)

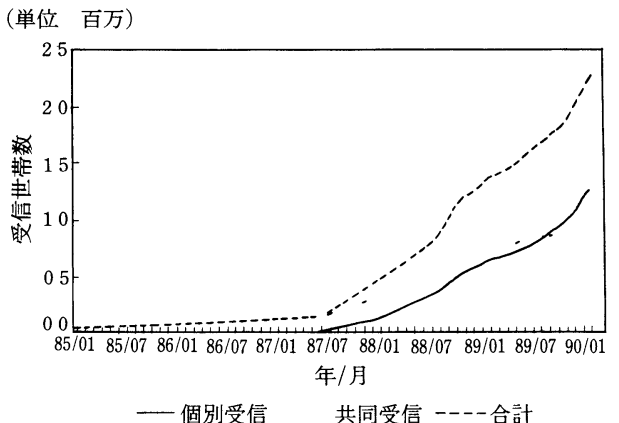

囚 3 衛星放送受信世帯数の推移 ${ }^{3)}$

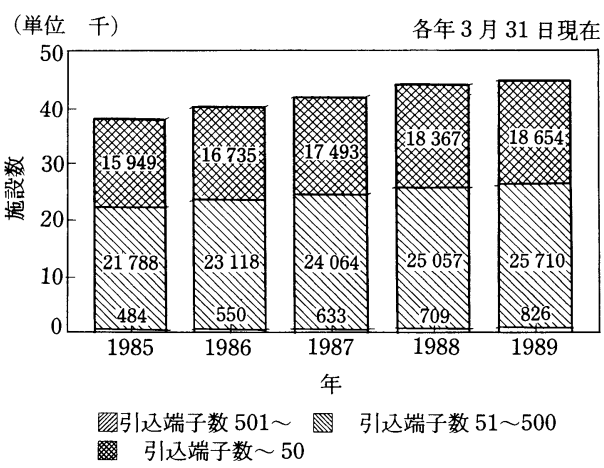

凶 4 CATV の規模別施設数 ${ }^{3)}$

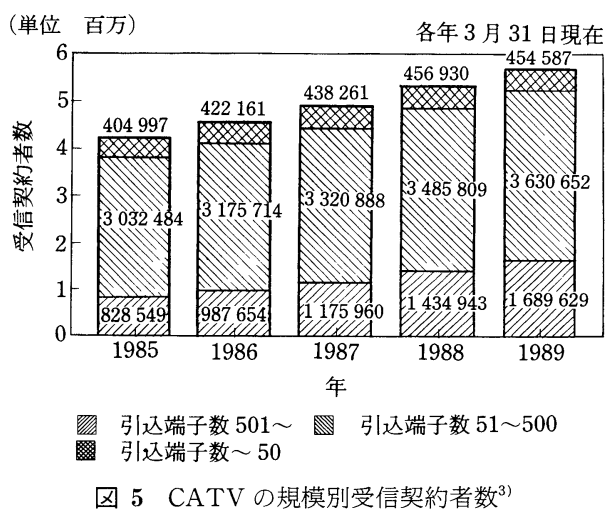

テレヒション学会䛃 Vol 44, No 7,pp 912９14（1990） 


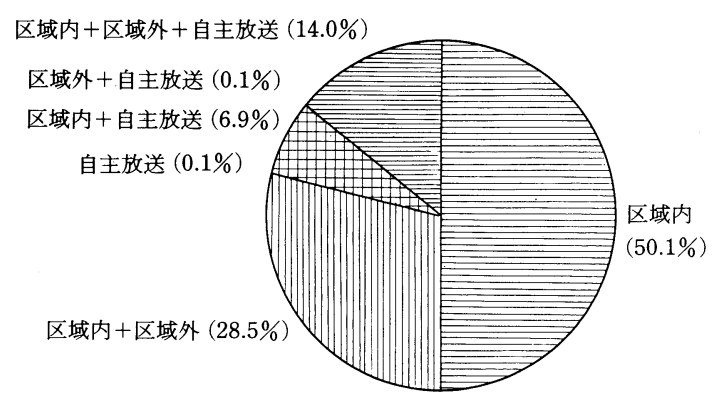

区域外 $(0.2 \%)$

(1989年 3 月 31 日現在)

図 $6 \mathrm{CATV}$ 施設の業務別区分 ${ }^{3)}$ (端子数 501 以上の施設)

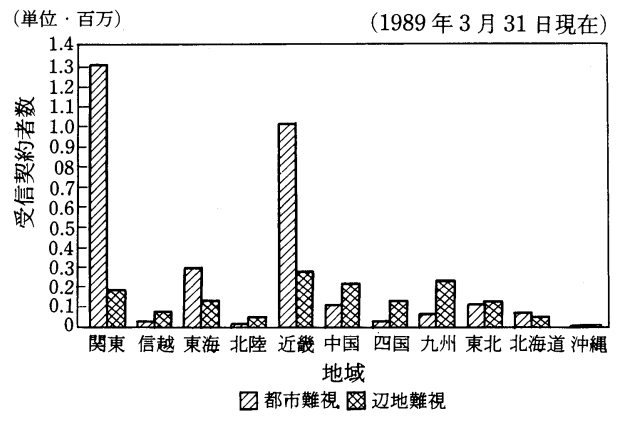

図 7 難視聴の原因別 CATV 受信契約者数 ${ }^{3)}$

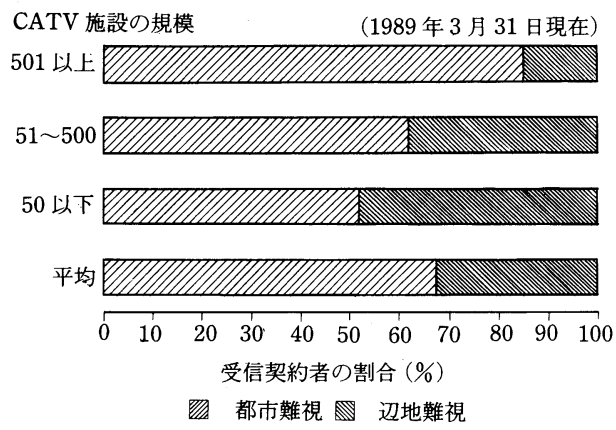

図 8 難視聴の原因別 CATV 受信契約者数の割合 ${ }^{3)}$

数は 600 万に迫っている。これは，NHK 受信契約世 帯数の 18\%になる（図 4，図 5). CATV の規模では， 引込端子数が少ない施設ほど多く, 引込端子数 100 以 下の施設が全体の $67 \%$ を占めている．CATV 施設の 業務内容を見ると，地上波 TV 放送の区域内あるい は区域外再送信のみの施設が大部分である（図 6). 端 子数 500 以下の施設では，区域内再送信が $74 \%$, 区 域外再送信を合わせると $99.6 \%$ とさらに顕著になる。 これより，難視聴対策としての施設が多いことがわか る. 難視の原因では関東・東海・近畿圏は, 都市難視

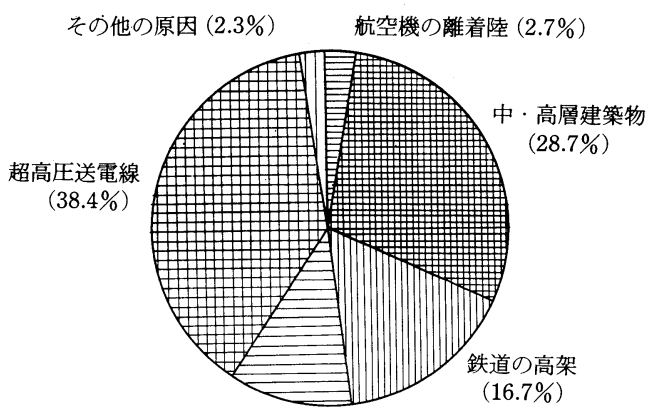

高速道路 (11.1\%)

(1989 年 3 月 31 日現在)

図 9 補償施設の原因別分類 ${ }^{3)}$ (引込端子数 501 以上 の施設, 総数 515)

（原因が建築物など人為的なもの）が多く，その他の地 域では辺地難視（地形など自然的原因によるもの）が 多くなっている（図 7)。また施設の規模から見ると， 大規模な施設ほど都市難視の割合が多くなっている (図 8). 難視聴の原因者が，その建設・運営費を負担 している CATV 施設（補償施設）は，引込端子数 501 以上の施設では 826 施設中 515 施設となっている。そ の原因別内訳は図 9 の通りである.

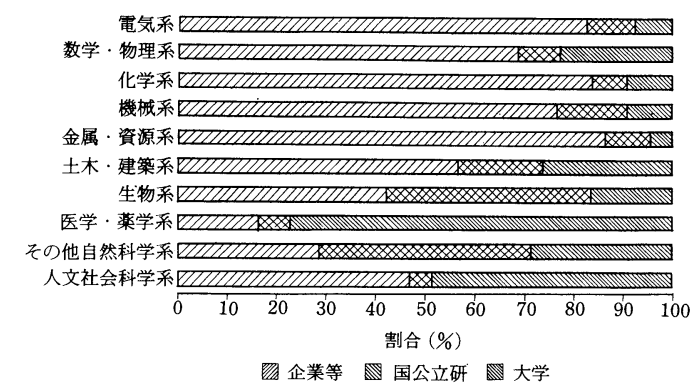

図 10 研究人材の採用実績 (産管学の内訳 $)^{4)}$

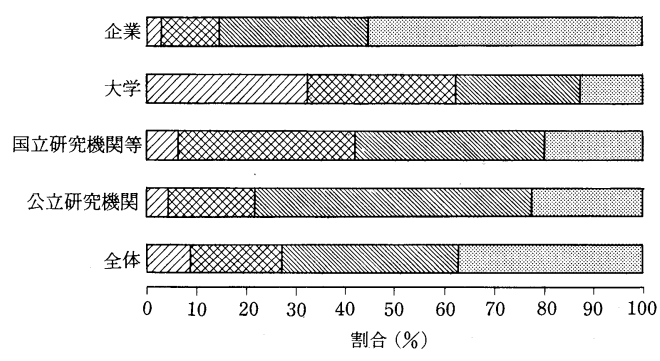

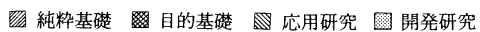

図 11 研究人材の稼働率から見た研究の性格別割合4) 


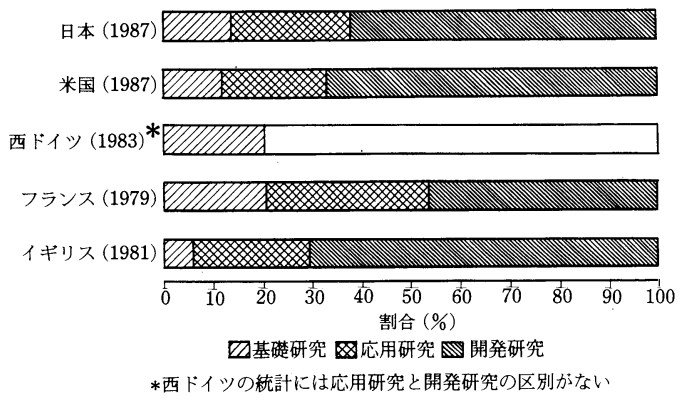

図 12 主要国の研究費の性格別構成比 ${ }^{5)}$

\section{2 研究に関する統計}

電気・情報系の技術者, 研究者の職場は, 採用実績 からみると企業等に $80 \%$, 国公立研究機関と大学に 各々 $10 \%$ となって打り, 工学系のなかでも企業の占め る割合が多い方に属する（図 10）。次に研究の性格を 研究者の数からみると, 全体の $28 \%$ が基礎研究に従 事し， $72 \%$ が応用・開発研究に従事している。基礎研 究の比重が高い大学でも, $38 \%$ の人材が応用・開発研 究を行っている (図 11). 一方, 研究費から見ると, $62 \%$ が開発研究であり，ついで応用研究が $24 \%$ とな っている(図 12). 研究費の面で, 主要先進国と比較 して日本の基礎研究の比率が特に低いわけではない.
NTT 通研

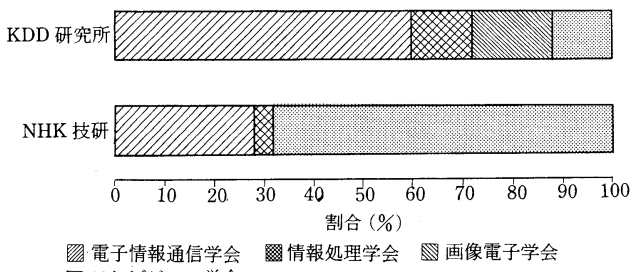

圆テレビション学会

図 13 学会誌への投稿状況 ${ }^{6}$ (1988 年 1 年間の論文投 稿者数の割合)

なお図 12 で，米国とフランスは人文科学を含む。ま たイギリスの統計には大学が, 西ドイツの統計には民 営研究機関が含まれていない。

研究の発表がどのように行われているかを, 国内学 会への投稿状況から見る.ここでは主要 3 研究機関に ついての統計を示す (図 13).

(1990 年 4 月 2 日受付)

〔参 考 文 献]

1) NHK 年鑑

2）民放便覽

3）郵政省放送行政局資料

4）科学技術庁資料

5) 科学技術白書

6）郵政省通信政策局資料 